\title{
Prospects for improving sweet cherry assortment in the conditions of the Central Chernozem region
}

\author{
R.E. Bogdanov", A.V. Kruzhkov, A.N. Yushkov, N.V. Borzykh, and M.I. Kozaeva \\ FSSI “I.V. Michurin FSC”, 393774, Michurinsk, Russia
}

\begin{abstract}
The research was aimed at evaluating sweet cherry forms on a complex of economically valuable traits and the allocation of promising genotypes for further use in breeding and production. The forms of sweet cherries grow in Michurinsk city of Tambov region. The study of frost resistance was carried out in laboratory conditions. Annual branches were frosted for 12 hours at $-32^{\circ} \mathrm{C}$ and $-35^{\circ} \mathrm{C}$. Reproductive buds in all studied forms were characterized by reversible damage (less than 3 points) at temperature regime $-32^{\circ} \mathrm{C}$ and complete death at $-35^{\circ} \mathrm{C}$. $10-117$ form was characterized by $-35^{\circ} \mathrm{C}$ frost resistance in the middle of winter, in which the freezing degree of annual branches tissues and vegetative buds did not exceed 2 points. Over the years of research, elites $4 / 8-24,10-115,7-38,10-$ $117,6-87,4 / 9-15,7-5$ possessed resistance to moniliosis and coccomycosis (the damage degree not more than 2 points). The highest yield (9.75-9.84 $\mathrm{t} / \mathrm{ha}$ ) on average over three years was shown by forms $4 / 8-24,7-38,7-5$. Yield at the control level was noted in forms 6-87, 4/9-15, 10-115. Elite forms 4/9-15, 7-38 were characterized by the largest mass of fruits, significantly exceeding the control variety. The average weight amounted to 7.3 and $7.2 \mathrm{~g}$, and the maximum was 9.4 and $8.4 \mathrm{~g}$ respectively. Forms $4 / 8-24,4 / 9-15,7-38$ combined the dessert taste of fruits (tasting assessment of 4.6-4.8 points), very juicy and dense pulp.
\end{abstract}

\section{Introduction}

Historically, the agro-industrial complex is one of the key industries of the Central Chernozem region. According to available data, the constituent CCR areas are among the most promising regions in terms of AIC development. In 2018, Belgorod, Voronezh, Kursk, Lipetsk, Oryol and Tambov regions accounted for about $27 \%$ of meat, $8 \%$ milk and eggs, $20 \%$ grain. In total, about $18 \%$ of domestic agricultural products were produced on their territory. At the same time, the average indices of the industry growth rate amounted to $3.5 \%$ with recession $(-0.2 \%)$ for the country as a whole [1].

The positive development dynamics of livestock and crop production of the Central Chernozem region continued in 2019. Thus, the average yield of grain crops exceeded the average Russian indicators by $40-50 \%$, and $5-10 \%$ - yield in the south of the country [2].

\footnotetext{
* Corresponding author: vniigispr3@yandex.ru
} 
Against the background of the coronavirus pandemic, past year was characterized by negative impact on the economy of these CCR regions, the Russian Federation, and the world. Nevertheless, several agricultural producers did not slow down on the development pace during this difficult period and continued implementing their projects. So, the total budget of the largest investment projects related to the improvement and modernization of Chernozem region agriculture implemented in 2020 amounted to 432.6 billion rubles [3].

In addition to cereals production, the Central Chernozem region is rightly famous for its high yield of potatoes, sugar beet, sunflower, canola, and soybeans. Unfortunately, against this background, the successes of fruit growing look somewhat more modest. And there are objective reasons. The cultivation of fruits and berries is one of the most promising and profitable areas in the agro-industrial complex, but horticulture development is impossible without serious investment, while their payback term is very long. This imposes a certain imprint on the mass of entrepreneurs' choice of horticulture as a source of basic income, but those who choose to produce fruits and berries are confident in their success on the basis of preliminary calculations and first achieved results [4-6].

It should be noted that horticulture products are an indispensable component of healthy and full nutrition of the population. This is due to the accumulation of easily digestible carbohydrates, vitamins, carotenoids, phenolic compounds, pectin, micro and macronutrients in the fruits. The most important task of the industry is the year-round, uninterrupted provision of high-quality products to the population. However, at the moment, own production is not able to satisfy the consumer market in full. The high need for fresh fruits causes a significant share of these products' imports, which negatively affects the provision of food security of the Russian Federation [7-13].

In the Russian Federation, according to the All-Russian agricultural census as of 2016 [14], the area under agricultural crops including perennial plantations in many respects is determined by regional features, as reflected in table 1 .

Table 1. Crop areas in the Russian Federation

\begin{tabular}{|c|c|c|c|}
\hline & \multicolumn{3}{|c|}{ Area } \\
\cline { 2 - 4 } & Crops, thousand & \multicolumn{2}{|c|}{ Perennial plantings } \\
\cline { 3 - 4 } & hectares & Thousand ha & \% of total \\
\hline Russian Federation & 79222.0 & 464.1 & 0.6 \\
\hline Central Chernozem region & 9807.4 & 66.9 & 0.7 \\
\hline Belgorod region & 1433.8 & 9.9 & 0.7 \\
\hline Voronezh region & 2529.2 & 20.1 & 0.8 \\
\hline Kursk region & 1629.4 & 7.4 & 0.5 \\
\hline Lipetsk region & 1329.6 & 12.9 & 1.0 \\
\hline Oryol region & 1252.7 & 5.7 & 0.5 \\
\hline Tambov region & 1632.7 & 10.7 & 0.7 \\
\hline
\end{tabular}

The proportion of perennial plantings in the agricultural areas structure in the Central Chernozem region is generally comparable to that of the country. The leader in absolute area value for perennial plantings is Voronezh region. However, according to the ratio of the area for gardens and berry grounds to the farmland area, the leadership belongs to the Lipetsk region. This is due to both weather and climatic conditions of the territory, as well as historical features [14].

The demand for domestic horticulture products contributes not only to the need for import substitution, but also a predisposition to local fruits consumption. Grown on the fertile lands of the Central Chernozem region, they often outperform imported products in terms of quality and biochemical composition [7].

Of particular importance for the economy of the Chernozem region is the cultivation of crops having extremely high popularity among the population, and they themselves are 
suitable for growing in the conditions of the region by their biological characteristics. Among the promising fruit crops grown on the CCR territory, sweet cherry [15-16] is of particular interest. However, the areas of this crop in the structure of the Central Chernozem stone fruit plantations are relatively small [14], which is reflected in table 2.

Table 2. Area of stone fruit crops in the Central Chernozem region

\begin{tabular}{|c|c|c|c|}
\hline \multirow{2}{*}{} & \multicolumn{3}{|c|}{ Area } \\
\cline { 2 - 4 } & \multirow{2}{*}{$\begin{array}{c}\text { Stone fruit } \\
\text { crops, ha }\end{array}$} & \multicolumn{2}{|c|}{ Sweet cherry } \\
\cline { 3 - 4 } & 124309.4 & 11012.7 & ha of total \\
\hline Russian Federation & 9192.7 & 628.4 & 6.8 \\
\hline Central Chernozem region & 1590.6 & 151.9 & 9.5 \\
\hline Belgorod region & 3131.7 & 211.0 & 6.7 \\
\hline Voronezh region & 997.2 & 54.8 & 5.5 \\
\hline Kursk region & 1676.2 & 121.5 & 7.2 \\
\hline Lipetsk region & 937.8 & 43.5 & 4.6 \\
\hline Oryol region & 859.2 & 45.7 & 5.3 \\
\hline Tambov region & \multicolumn{2}{|c}{} \\
\hline
\end{tabular}

Voronezh region is characterized by the largest plantings' area of both stone fruit and sweet cherry in particular. Lipetsk and Belgorod regions are inferior to it in the number of sweet cherry orchards, but they surpass the Voronezh region in the proportion of sweet cherry in the structure of perennial stone fruit crops [14].

In the world, 416,5 thousand hectares are employed for sweet cherry plantings. The global fruits' harvest is 2443,7 thousand tons, of which about $1.7 \%$ accounts for the Russian Federation. The average yield of sweet cherry in the world is $5.9 \mathrm{t} / \mathrm{ha}$, in Russia $-4.1 \mathrm{t} / \mathrm{ha}$. [17]. The population's need for sweet cherry fruits is realized both at the expense of own production and through imports. In recent years, the volume of sweet cherry import to Russia reaches 70-110 thousand tons according to different estimates [18].

As a reserve for increasing the gross harvest of sweet cherry fruits, the increase in crop areas in farms and small agricultural organizations deserves special attention. A significant role in this is played by the susceptibility of these manufacturers for innovative development of advanced industries. With some government support, this will contribute both to the efficient cultivation of products and its storage and processing [19]. Sweet cherry cultivation in organic agriculture is of particular interest; it will produce minimal harm to the environment and will allow to obtain safe fresh fruits and food based on them.

Compliance with basic principles of organic agriculture, including giving up on synthetic plant protection products will require to create varieties adapted to cultivation in the framework established by the concept.

Low temperatures cause significant damage to fruit plants' plantations on the territory of the Central Chernozem region. It should be noted that sweet cherry belongs to crops with relatively low winter resistance. The historical range of its cultivation in our country corresponds with the southern regions (North Caucasus, Southern Federal Districts). The cultivation of sweet cherry to the north of them was ineffective and was the focus of just a few amateur gardeners. Work on the varieties' creation suitable for growth in the CDR began only in the XX century and is associated with the name of I.V. Michurin and the national scientific school established by him $[16,20]$.

The peculiarities of weather and climatic conditions of the region should include periodically repeated harsh winters, which must be considered when choosing the main directions of crop selection. In this regard, in Chernozem, sweet cherry varieties' resistance to low temperatures is largely determined by their maximum frost resistance (II component of winter resistance) [16, 21-24]. 
The ability of plants to effectively resist the effects of adverse biotic stressors is another critical characteristic of a modern variety [25]. Like a number of other stone fruit crops, sweet cherry is affected by various types of fungal diseases, among which coccomicosis (pathogen Coccomyces hiemalis Higg.) and moniliosis (pathogen Monilia fructigena Pers. and Monilia cinerea Bon.) should be distinguished. Diseases impact leads to biological cycle violation of affected trees, loss of fruit quality and yield, plants weakening, and often - their death [16].

According to available literary data, sweet cherry is relatively more resistant to coccomicosis and moniliosis compared to other species of the Prunus L. genus. However, the intra-species sweet cherry resistance to diseases is heterogeneous and varies greatly depending on a particular variety. The situation is aggravated by the emergence of new phenotypes and races of pathogens, as well as changes in weather and climatic conditions, which cause additional impact on crops [16, 26-28]. The creation of new varieties with natural genetic resistance to biotic stressors is entirely consistent with the organic horticulture requirements and is of considerable interest to traditional industrial work in plantings, since when achieving the same goals, the use of chemical protection products is significantly minimized, and therefore the corresponding costs are reduced.

The economic value of a variety is determined by the yield, commercial and consumer qualities of fruits. Genotype characteristics according to these traits has a crucial role in the variety allocation and its transfer to the State strain testing.

Yield is the result of the variety's productivity potential realization in specific environmental conditions and it is formed under the influence of abiotic and biotic factors [29]. The most important commercial and consumer qualities of stone fruit crops, and in particular sweet cherry, include the diameter and weight of the fruit, as well as the size of its stone and the ratio of stone weight to fruit weight. For the commercial market, the most interest is varieties with intensive-colored large fruit and small stone suitable for transport. For fresh consumption, fruits should possess dessert taste [16].

To improve the industry efficiency, continuous improvement and existing variety composition updating is necessary. In the FSSI "I.V. Michurin FSC", active breeding work on sweet cherries is carried out [30]. The share of the institution accounts for $50 \%$ of varieties included in the State Register and admitted for use in the Central Chernozem region [31]. This paper presents the results of a comprehensive assessment of sweet cherry forms promising for cultivation in the CCR conditions.

\section{Materials and methods}

The study of 10 elite sweet cherry forms of FSSI "I.V. Michurin FSC" selection was carried out: 10-117, 10-115 (seedlings of Rostovchanka variety), 6-87 (seedlings of selected form 17-60), 7-38, 4/9-15, 4/8-24, 8-95, 7-5 (Rossoshanskaya variety seedlings), 1-39-01 (Rodina x Fatezh), 1-54-01 (O-3 x Italianka). Rodina variety allowed for use in the Central Chernozem region was used as control. This variety was characterized by average indicators of frost resistance, resistance to the most common fungal diseases, yield (during favorable years productivity was significantly higher than average crop indicator), high commercial and consumer qualities of fruits. Experimental plantings were laid out in 2014. The planting scheme $-6 \times 3 \mathrm{~m}$. The study was carried out in 2018-2020.

Assessment of mid-winter frost resistance was carried out in laboratory conditions using generally accepted methodological recommendations [32]. In November-December, annual branches were cut and stored under snow or climate chambers at a temperature of $-1 \ldots-2^{0} \mathrm{C}$. Conditioning was conducted at -5 and $-10^{\circ} \mathrm{C}$ for 5 days in the MLR-350 climate chamber. Frosting was carried out at temperatures $-32 \ldots-35^{\circ} \mathrm{C}$ for 12 hours in chamber SM-60/100250 TX. 
Features of fungal pathogens development were studied against a natural background. The development intensity was assessed in points using a quantitative scale $[33,34]$. The yield and commercial and consumer qualities of fruits were studied according to the standard methodology [34].

\section{Results and discussion}

The stability assessment of perspective sweet cherry forms was carried out at temperature conditions -32 and $-35^{\circ} \mathrm{C}$. When the temperature was reduced to $-32^{\circ} \mathrm{C}$, most of the studied forms were characterized by minor tissue and vegetative buds damage not exceeding 2 points. In all studied forms, the death of individual reproductive rudiments was noted. The average freezing score of floral buds varied between 2.1 and 2.4 points.

Reduction of freezing temperature to $-35^{\circ} \mathrm{C}$ made it possible to identify significant frost resistance differences in the studied forms as presented in table 3 . Wood was characterized by the greatest damage from the tissues of annual branches. In the elite form 7-5, the smallest freezing of xylem (0.5 points) was noted. Forms 4/8-24, 8-95, 4/9-15 were also characterized by minor damage to this tissue not exceeding 1 point. Rodina variety and elite 7-38, 10-117 were characterized by frost-resistant wood (the freezing degree no more than 2 points). The average xylem stability was noted in forms $6-87,10-115$, in which the freezing was 2.1 and 2.2 points, respectively. Significant differences from the described forms were shown by elites 1-54-01, 1-39-01. In these forms, wood is low winter proof, the damage degree was 3.5 and 4 points respectively.

Table 3. Frost resistance of sweet cherry varieties and forms (2018-2020)

\begin{tabular}{|c|c|c|}
\hline \multirow{2}{*}{ Variety, form } & \multicolumn{2}{|c|}{ Freezing at $\mathbf{- 3 5}^{\mathbf{0}} \mathbf{C}$, score } \\
\cline { 2 - 3 } & Wood & Vegetative buds \\
\hline $10-117$ & 2.0 & 1.2 \\
\hline $10-115$ & 2.2 & 1.5 \\
\hline $6-87$ & 2.1 & 2.0 \\
\hline $7-38$ & 1.3 & 2.3 \\
\hline $4 / 9-15$ & 0.9 & 2.4 \\
\hline Rodina (c) & 1.5 & 2.4 \\
\hline $4 / 8-24$ & 0.7 & 2.5 \\
\hline $8-95$ & 0.7 & 2.6 \\
\hline $7-5$ & 0.5 & 2.7 \\
\hline $1-39-01$ & 4.0 & 3.0 \\
\hline $1-54-01$ & 3.5 & 3.4 \\
\hline LCD 05 & 1.2 & 0.9 \\
\hline
\end{tabular}

With this freezing temperature regime, vegetative buds in most studied forms had a more serious freezing in comparison with wood, which is reflected in table 3. Elite 10-117, $10-115,6-87$ were characterized by frost resistance of these organs, the damage degree did not exceed 2 points. Average resistance of vegetative buds to temperature decrease to $-35^{\circ} \mathrm{C}$ was noted in the control variety Rodina and forms 7-38, 4/9-15, 4/8-24, 8-95, 7-5, 1-39-01. The freezing degree in this group varied from 2.3 to 3.0 points. Low frost resistance of both wood and vegetative buds (the degree of damage of 3.4 points) was shown by the form 1 54-01.

Generative buds are the most vulnerable to frost effects. Mid-winter temperature reduction to $-35^{\circ} \mathrm{C}$ caused the complete death of generative rudiments in all studied forms.

The general condition of plants, yield, qualitative indicators of fruits are largely determined by resistance to biotic stressors. Over the years of research, the spread of coccomycosis and moniliosis pathogens has been observed in sweet cherry plantings. The 
damage degree by fungal pathogens to the studied forms is presented in table 4 . Control variety Rodina and most of the studied forms were characterized by high resistance to coccomicosis, the damage degree did not exceed 1 point. In the form 1-39-01, the intensity of this disease's development was 1.1 points.

In the composition of exophytic microbiota the manifestation of Monilia fructigena Pers. + Monilia cinerea Bon. pathogen complex was noted, among which the causative agent of gray mold prevailed. These species belong to the juntor group and are characterized by a tendency to lose the ascigerous stage, the absence of disjuntors in the conidial chain. It should be pointed out that the moniliosis manifestation on sweet cherry plants was noted during flowering in the form of a burn, during mass fruit ripening in the form of spur blight. Mass monilial blight distribution in all studied forms during the years of study was not revealed. The development degree of this disease did not exceed 1 point. Monilia cinerea Bon. gray rot pathogen had dominant distribution on fruits. Elites 4/8-24, $10-115,7-38,10-117,6-87,4 / 9-15,7-5$ were characterized by high resistance to fruit rot. The maximum disease development during the years of research did not exceed 1 point. The control variety Rodina and 8-95 form were included in resistant group (development intensity 1.8 points). A damage of 2.1 and 2.4 points respectively was noted in forms $1-54$ 01, 1-39-01.

Table 4. Resistance of sweet cherry varieties and forms to fungal diseases (2018-2020)

\begin{tabular}{|c|c|c|c|}
\hline \multirow{2}{*}{ Variety, form } & \multicolumn{3}{|c|}{ Degree of disease affection, score } \\
\cline { 2 - 4 } & Coccomycosis & Monilial blight & Spur blight \\
\hline $4 / 8-24$ & 0.7 & 0.2 & 0.3 \\
\hline $10-115$ & 0.5 & 0.5 & 0.4 \\
\hline $7-38$ & 0.4 & 0.1 & 0.5 \\
\hline $10-117$ & 0.6 & 0.4 & 0.5 \\
\hline $6-87$ & 0.4 & 0.3 & 0.7 \\
\hline $4 / 9-15$ & 0.3 & 0.2 & 0.8 \\
\hline $7-5$ & 0.5 & 0.6 & 0.9 \\
\hline $8-95$ & 0.4 & 0.7 & 1.8 \\
\hline Rodina (c) & 0.9 & 0.5 & 1.8 \\
\hline $1-54-01$ & 1.0 & 0.9 & 2.1 \\
\hline $1-39-01$ & 1.1 & 0.8 & 2.4 \\
\hline LCD 05 & 0.5 & 0.4 & 1.3 \\
\hline
\end{tabular}

One of the most important indicators determining the variety value is yield. During the years of research, significant differences in the studied forms of sweet cherry have been revealed by yield as shown in table 5 .

Table 5. Yields of sweet cherry varieties and forms (2018-2020)

\begin{tabular}{|c|c|}
\hline Variety, form & Yield, t/ha \\
\hline $4 / 8-24$ & 9.84 \\
\hline $7-38$ & 9.77 \\
\hline $7-5$ & 9.75 \\
\hline Rodina (c) & 9.03 \\
\hline $6-87$ & 8.93 \\
\hline $4 / 9-15$ & 8.08 \\
\hline $10-115$ & 7.26 \\
\hline $10-117$ & 6.12 \\
\hline $8-95$ & 6.04 \\
\hline $1-54-01$ & 5.87 \\
\hline $1-39-01$ & 5.89 \\
\hline LCD $_{05}$ & 1.94 \\
\hline
\end{tabular}


The average control variety yield amounted to $9.03 \mathrm{t} / \mathrm{ha}$. At forms $4 / 8-24,7-38,7-5$ this indicator exceeded the control and ranged from 9.75 to $9.84 \mathrm{t} / \mathrm{ha}$. A slight productivity decrease relative to the control variety was revealed in elites $6-87,4 / 9-15,10-115$. It averaged to 7.26-8.93 t/ha over the years of research depending on form. Elite forms 10 $117,8-95,1-54-01,1-39-01$ showed a significant yield decrease compared to the control variety, in which this indicator varied within 5.89-6.12 t/ha.

The most important indicator of commercial grade is the quality of fruit. This trait is complex. When assessing it, the appearance, weight, coloring, pulp juiciness, taste, etc. are considered. The forms studied were characterized by significant differences in the size of the fruit as reflected in table 6 .

Table 6. Fruit size

\begin{tabular}{|c|c|c|c|c|c|}
\hline \multirow{2}{*}{$\begin{array}{c}\text { Variety, } \\
\text { form }\end{array}$} & $\begin{array}{c}\text { Fruit } \\
\text { diameter, } \\
\text { mm }\end{array}$ & \multicolumn{2}{|c|}{ Fruit weight, $\mathbf{g}$} & \multirow{2}{*}{$\begin{array}{c}\text { Stone } \\
\text { weight, }\end{array}$} & $\begin{array}{c}\text { Ratio of stone } \\
\text { weight to fruit } \\
\text { weight, \% }\end{array}$ \\
\hline $4 / 9-15$ & $24.4 \pm 0.06$ & $7.3 \pm 0.33$ & $9.4 \pm 0.27$ & $0.57 \pm 0.03$ & 7.9 \\
\hline $7-38$ & $24.2 \pm 0.06$ & $7.2 \pm 0.32$ & $8.4 \pm 0.25$ & $0.51 \pm 0.02$ & 7.1 \\
\hline $10-117$ & $24.1 \pm 0.05$ & $7.0 \pm 0.31$ & $7.5 \pm 0.23$ & $0.46 \pm 0.02$ & 6.5 \\
\hline Rodina (c) & $24.3 \pm 0.06$ & $6.4 \pm 0.15$ & $7.6 \pm 0.14$ & $0.36 \pm 0.02$ & 5.7 \\
\hline $8-95$ & $22.3 \pm 0.05$ & $6.3 \pm 0.15$ & $7.1 \pm 0.13$ & $0.52 \pm 0.03$ & 8.3 \\
\hline $10-115$ & $22.2 \pm 0.06$ & $6.1 \pm 0.21$ & $6.6 \pm 0.18$ & $0.32 \pm 0.01$ & 5.3 \\
\hline $6-87$ & $22.1 \pm 0.05$ & $5.9 \pm 0.13$ & $6.3 \pm 0.11$ & $0.40 \pm 0.02$ & 6.8 \\
\hline $4 / 8-24$ & $23.9 \pm 0.04$ & $5.2 \pm 0.16$ & $7.2 \pm 0.14$ & $0.32 \pm 0.01$ & 6.2 \\
\hline $7-5$ & $22.0 \pm 0.04$ & $5.1 \pm 0.08$ & $6.5 \pm 0.7$ & $0.40 \pm 0.01$ & 7.8 \\
\hline $1-54-01$ & $21.3 \pm 0.03$ & $4.8 \pm 0.12$ & $5.3 \pm 0.11$ & $0.32 \pm 0.01$ & 6.7 \\
\hline $1-39-01$ & 21.10 .03 & $4.7 \pm 0.12$ & $5.2 \pm 0.11$ & $0.31 \pm 0.01$ & 6.6 \\
\hline
\end{tabular}

The control variety Rodina was characterized by large size of fruit. The average fruit weight was $6.4 \mathrm{~g}$, the maximum - $7.6 \mathrm{~g}$. The largest fruit size is noted in the form 4/9-15 (diameter $24.4 \mathrm{~mm}$, average weight $7.3 \mathrm{~g}$, maximum $9.4 \mathrm{~g}$ ). Elites 7-38, 10-117 also differed in significantly higher average fruit weight relative to control, but in the latter form the diameter and maximum fruit weight were lower than the control variety. Elite 7-38 was also inferior to control in fruit diameter.

The remaining studied forms were part of the group with an average fruit size. It should be noted that the form 10-115 had insignificant differences of average weight from control. However, the diameter and maximum fruit weight were significantly below control. In elites 6-87, 4/8-24, 7-5, the average fruit weight exceeded $5 \mathrm{~g}$. Of these, the 4/8-24 form had the largest diameter $(23.9 \mathrm{~mm})$ and maximum $(7.2 \mathrm{~g})$ fruit weight. Forms 1-54-01 and 1-39-01 were characterized by the smallest measurements of fruit size. It should be noted that in all studied forms, the average fruit weight is a more stable indicator in comparison with the maximum weight.

When evaluating the fruit quality, the stone weight is considered as well as its share in the total fruit weight [35]. Very large $(0.57 \mathrm{~g})$ stone was noted in the elite $4 / 9-15$, but in relation to the fruit weight $(7.9 \%)$ it was classified as large. Elite forms $8-95,7-38$ were a part of large stone group both in absolute weight and in the ratio of stone to total weight. Despite the large stone weight, form 10-117 was characterized by an average ratio to the fruit weight. The remaining studied forms were characterized by averages of both indicators. The stone weight of the control variety Rodina was $0.36 \mathrm{~g}$, and the ratio to the fruit weight - 5.7\%. A smaller stone weight (0.31-0.32 g) was noted in elites 10-115, 4/824, 1-39-01. 10-115 form was also characterized by the smallest stone share in the total fruit weight.

The commercial variety should have an attractive appearance, juicy dense pulp, pleasant taste. The forms studied were characterized by different combinations of these traits as 
shown in table 7 . The 4/8-24 form fruits combined dessert taste (4.8 points), a very juicy and very dense pulp with an attractive bright yellow color of the skin. The dessert fruit taste (4.6-4.8 points) was also a characteristic of elites 4/9-15, 6-87, 10-117, 7-38. Forms 4/9-15, 7-38 stood out from this group by attractive coloring, very juicy and dense pulp. 6-87, 10117 elites had dark skin coloring, juicy pulp. However, the fruit pulp was characterized by an average density, which negatively affected the fruit transportability. The remaining forms had fruit of a table purpose (tasting score of 4.4-4.5 points).

Table 7. Commercial and consumer qualities of fruits

\begin{tabular}{|c|c|c|c|c|}
\hline $\begin{array}{c}\text { Variety, } \\
\text { form }\end{array}$ & $\begin{array}{c}\text { Fetal } \\
\text { coloring }\end{array}$ & Juiciness & Density & $\begin{array}{c}\text { Tasting score, } \\
\text { points }\end{array}$ \\
\hline $4 / 8-24$ & Yellow & Very juicy & Very dense & 4.8 \\
\hline $4 / 9-15$ & Red & Very juicy & Dense & 4.8 \\
\hline $6-87$ & Dark red & Juicy & Average & 4.7 \\
\hline $10-117$ & Dark red & Juicy & Average & 4.7 \\
\hline $7-38$ & Light Red & Very juicy & Dense & 4.6 \\
\hline $7-5$ & Light Red & Very juicy & Dense & 4.5 \\
\hline Rodina & Dark red & Juicy & Average & 4.5 \\
\hline $8-95$ & Brown red & Juicy & Average & 4.5 \\
\hline $10-115$ & Dark red & Average & Dense & 4.5 \\
\hline $1-54-01$ & Red & Juicy & Average & 4.4 \\
\hline $1-39-01$ & Red & Juicy & Soft & 4.4 \\
\hline
\end{tabular}

The control variety Rodina and form 8-95 combined a very dark skin color, juicy pulp with an average value of its density. Elite 7-5 had a very juicy and dense pulp. The skin of this form had a yellow color with red blush on the most part. Elite 10-115 along with dark skin coloring and dense pulp was characterized by medium juiciness. The forms 1-54-01, 1-39-01 were characterized by low pulp density.

\section{Conclusions}

On the basis of a comprehensive assessment of promising sweet cherry forms, genotypes with outstanding traits have been identified:

- frost resistance of tissues and vegetative buds (the freezing degree not more than 2 points) in mid-winter $\left(-35^{\circ} \mathrm{C}\right)$ : $10-117$;

- resistance to the most common fungal diseases: 4/8-24, 10-115, 7-38, 10-117, 6-87, 7 5, 4/9-15;

- yield: 4/8-24, 7-38, 7-5, 6-87, 4/9-15, 10-115;

- large size and attractive appearance of fruits: 4/9-15, 7-38, Rodina, 10-117, 8-95;

- dessert taste, very juicy and dense fruit pulp: 4/8-24, 4/9-15, 7-38.

\section{References}

1. Chernozem region - the driver of Russian agribusiness, https://chr.plus.rbc.ru

2. Chernozem region is on the path of intensification, https://chr.plus.rbc.ru

3. The largest investment projects in the Chernozem region in 2020, https://agrovesti.net

4. A.A. Polukhin, S.D. Knyazev, I.A. Efremov, The conceptual model of innovative development of industrial gardening, 282, 333 (2020)

5. Chernozem region AIC: a trend for sustainable development, https://chr.plus.rbc.ru

6. A. Skripka, Chernozem region's bet on gardening, https://rg.ru 
7. M.Yu. Akimov, V.V. Bessonov, V.M. Kodentsova, K.I. Eller, O.A. Vrzhesinskaya, N.A. Beketova, O.V. Kosheleva, M.N. Bogachuk, A.D. Malinkin, M.A. Makarenko, et al, Nutrition issues, 89(4), 220 (2020)

8. N.V. Borzykh, E.V. Zhbanova, R.E. Bogdanov, A.V. Kruzhkov, Breeding and cultivation of garden crops, 7(1-2), 30 (2020)

9. I.M. Kulikov, I.A. Minakov, AIC: Economy, management, 12, 66 (2017)

10. I.M. Kulikov, I.A. Minakov, Priority directions of horticulture development in conditions of import substitution, 114 (2020)

11. M.A. Makarkina, T.V. Yanchuk, S.D. Knyazev, Evaluation and selection of raw material for black currant selection to improve the chemical composition of berries, 168 (2017)

12. V.A. Tuteljan, Chemical composition and calorie content of Russian food, 284 (2012)

13. N.A. Tsarenko, Herald of KrasSAU, 3, 49 (2010)

14. Federal Service of State Statistics, All-Russian Agricultural Census 2016, https://www.gks.ru

15. A.A. Gulyaeva, Cherry and sweet cherry, 52 (2015)

16. E.N. Dzhigadlo, Improvement of selection methods, creation of cherry and sweet cherry varieties, their rootstocks with ecological adaptation to the conditions of the Central region of Russia, 268 (2009)

17. FAOSTAT, http://fenixservices.fao.org

18. Ghost fruit or how many sweet cherries and from which countries does Russia actually import?, https://east-fruit.com

19. I.M. Kulikov, I.A. Minakov, Scientific Papers. Series: Management, Economic Engineering and Rural Development, 19(4), 141 (2019)

20. R.G. Nozdracheva, Sweet cherry. Zoned varieties. Cultivation experience in Chernozem region, 35 (2012)

21. R.E. Bogdanov, A.V. Kruzhkov, A.V. Kruzhkov, Identification and creation of sources and donors of selection-significant traits of stone fruit crops, 68 (2010)

22. A.N. Yushkov, Breeding of fruit plants for resistance to abiotic stressors, 332 (2019)

23. A.N. Yushkov, N.V. Borzykh, Fruit growing and berry growing in Russia, 56, 9 (2019)

24. Z. Ozherelieva, E. Sedov, Proceedings of the Latvian Academy of Sciences, Section B: Natural, Exact, and Applied Sciences, 71(3), 127 (2017)

25. M.I. Kozaeva, Fruit growing and berry growing in Russia, 29(1), 233 (2012)

26. A.A. Gulyaeva, I.N. Efremov, T.N. Berlova, Modern horticulture, 4(24), 25 (2017)

27. M.S. Lenivtseva, A.P. Kuznetsova, E.E. Radchenko, Mycology and phytopathology, 50(1), 62 (2016)

28. M.S. Lenivtseva, E.E. Radchenko, A.P. Kuznetsova, Agricultural Biology, 52(5), 895 (2017)

29. R.Sh. Zaremuk, Yu.A. Dolya, T.A. Kopnina, Agricultural Biology, 55(3), 573 (2020)

30. R.E. Bogdanov, A.V. Kruzhkov, A.A. Konyukhova, Horticulture and viticulture, 4, 7 (2008)

31. FSBI "Gossortkomissiya", https://reestr.gossortrf.ru

32. M. M. Tyurina, G.A. Gogoleva, N.V. Efimova, Stability determination of fruit and berry crops to stressors of the cold season in field and controlled conditions: methodological recommendations, 119 (2002) 
33. V.V. Zhdanov, Program and methodology of variety study of fruit, berry and nut crops, 102 (1999)

34. E.N. Dzhigadlo, A.F. Kolesnikova, G.V. Eremin, T.V. Morozova, S.Yu. Debiskaeva, M.V. Kanshina, N.I. Medvedeva, V.S. Simagin, Program and methods of variety study of fruit, berry and nut crops, 300 (1999)

35. Broad unified Comecon classifier of Cerasus Mill. genus, 48 (1989) 